\title{
Method to Fit Paris Agreement for Protection of Global Warming
}

\section{Shoichiro Ozaki*}

Laboratory for Developmental Neurobiology, Brain Science Institute, Wako, Saitama, Japan

\begin{abstract}
Fossil fuel burn releasing 360 billion tonne heart and carbon-dioxide. Burning reaction is reverse reaction of carbon-dioxide assimilation. If we can compensate the generation of carbon-dioxide and heart of burning with the absorption of carbon-dioxide and heart by carbon-dioxide assimilation, global warming will be protected. To promote carbon-dioxide assimilation, supply of nutrient $\mathrm{N}$ and $\mathrm{P}$ is essential. 14.4 billion tonne NOx is produced when fossil fuel is burned. Many governments are eliminating NOx as pollution gas. Carbon-dioxide assimilation is retarded and 142 billion tonne carbon-dioxides is increasing each year. Large amount of $\mathrm{N}$ and $\mathrm{P}$ in drainage is eliminated using much electricity. If we stop elimination of NOx and N, P in drainage, 10 billion tonne carbon-dioxide emission will be saved and 142 billion tonne carbon-dioxide can be fixed to protect global warming. NOx in exhaust gas and $\mathrm{N}, \mathrm{P}$ in drainage should be released as it is. Promotion of carbon-dioxide assimilation is most important subject for protection of global warming. Elimination of law which forced to eliminate nutrient N,P and study on agitation of sea water are important subjects for the protection of global warming.
\end{abstract}

Keywords: $\mathrm{NO}_{x}$; $\mathrm{CO}_{2}$; Plankton $\mathrm{CO}_{2}$ assimilation; Global warming; Paris agreement; Plankton

\section{Introduction}

Fossil fuel burn releasing carbon-dioxide and heart. Carbon dioxide assimilation reaction is the reaction of carbon dioxide with water producing carbohydrate and $\mathrm{O}_{2}$ absorbing heart. Burning reaction is reverse reaction of carbon dioxide assimilation. If we can compensate the generation of carbon dioxide and heart of burning with the absorption of carbon dioxide and heart by carbon dioxide assimilation, global warming will be protected (1-5). Carbon dioxide is increasing in 1750278 ppm, 1985345 ppm, 1990357 ppm, 1995360 ppm, 2000 367ppm, 2005377 ppm, 2010387 ppm, 2015 400ppm. Carbon dioxide increasing $2.0 \mathrm{ppm}$ annually. Total amount of carbon dioxide in the world is $2.83 \times 10^{12}$ tonne.

Total emission of carbon dioxide in one year is $3.6 \times 10^{10}$ tonne. Almost all carbon dioxide is used for carbon dioxide assimilation of plant. This mean that all carbon dioxide in the world is replaced by new carbon dioxide in 7.8 years. Increase of carbon dioxide in one year is $2.83 \times 10^{12} \times 2 / 400=1.415 \times 10^{10}$ tonne (142 billion tonne). Therefore $3.6 \times 10^{10}-1.42 \times 10^{10}=2.18 \times 10^{10}$ tonne, 218 billion tonne. Carbon dioxide is fixed in one year. If we can increase the fix of carbon dioxide $1.41 \times 10^{10}$ tonne in year we can protect global warming. 142 billion tonne is $1 / 2.5$ of one year emission 360 billion tonne. I wish to describe the way to solve this problem.

\section{Effective Uses of $\mathrm{NO}_{\mathrm{x}}$ And $\mathrm{N}, \mathrm{P}$ In Drainage are Best Way to Conserve Global Warming and to Improve Food Production}

To increase the fix of carbon dioxide $1.42 \times 10^{10}$ tonne, we must increase the carbon dioxide assimilation. Carbon dioxide assimilation is accelerated by nutrient $\mathrm{N}, \mathrm{P}(6-13)$.

NOx in exhausts gas of car is hated as polluting gas. NOx hating is extended to electricity generation plant. NOx produced at electricity plant is so huge amount. NOx is essential compound for plant growth, production of food carbon dioxide assimilation. Many government set up the law to eliminate NOx. NOx in exhausts gas at the electricity plant was killed by ammonia. As the result carbon dioxide assimilation is depressed greatly and carbon dioxide fix is depressed greatly, and produced carbon dioxide cannot be fixed well and carbon dioxide 1.42 $\times 10^{10}$ tonne is remaining.

Toxicity of NOx of exhausts gas of car might be great. But NOx exhausted at electricity plant is not toxic just like NOx produced by thunder. Japan government eliminated NOx in all kind of gas and carbon dioxide assimilation is blocked and fish industry suffered critical damage. On the contrary China is using NOx and fish production increased and about 16 billion tonne $\mathrm{CO}_{2}$ was fixed. NOx elimination should be limited for the exhaust gas of car (12\%) and NOx elimination at electric power station (88\%) should not be done.

The amount of NOx composed is almost 14.4 billion tonne in worldwide. To eliminate NOx 14.4 billion tonne, equlmolar amount of ammonia 8.6 billion tonne is used. To make ammonia 8.6 billion tonne, 1.44 billion tonne hydrogen gas is used. To make 1.44 billion tonne hydrogen. Butan, 8.3 billion tonne is used. As the result 25.3 billion tonne carbon dioxide is released. If NOx elimination is stopped, 25.3 billion tonne carbon dioxide release can be stopped. And $14.4 \times$ $25=360$ billion tonne carbon dioxide can be fixed. Therefore if we stop the elimination of NOx, and stop the elimination of N, P in drain, we can stop the global warming. In other word, if elimination of NOx and elimination of in drain N, P are not done, global warming would not happen.

Material balance of carbon dioxide, NOx, fish, grain, tree grass

Carbon dioxide emission, carbon dioxide res, NOx emission, fish production, carbon dioxide $\mathrm{f}$ (carbon dioxide fixing by plankton used for fish production), Grain, carbon dioxide g (carbon dioxide fixing

*Corresponding author: Shoichiro Ozaki, Laboratory for Developmental Neurobiology, Brain Science Institute, RIKEN, 2-1 Hirosawa, Wako, Saitama 351-0198, Japan, Tel: +81 0467670991; E-mail: ozaki-0991@jcom.zaq.ne.jp

Received December 02, 2017; Accepted December 20, 2017; Published December 27, 2017

Citation: Ozaki S (2017) Method to Fit Paris Agreement for Protection of Global Warming. Int J Waste Resour 7: 318. doi: 10.4172/2252-5211.1000318

Copyright: (c) 2017 Ozaki S. This is an open-access article distributed under the terms of the Creative Commons Attribution License, which permits unrestricted use, distribution, and reproduction in any medium, provided the original author and source are credited. 
used for grain production), carbon dioxide $t$ (carbon dioxide used for tree grass production, of many countries in the world are shown in Table 1.

Carbon dioxide emission; 360 billion tonne carbon dioxide was produced in the world in 2016 by the burning of 140 billion tonne fossil. To protect global warming, we must fix carbon dioxide same amount of carbon dioxide as emission.

We are emitting 360 billion tonne carbon dioxide. We are fixing 283 billion tonne. Therefore 142 billion tonne Carbon dioxide is increasing. We must fix 142 billion tonne carbon dioxide by proportion of emission of each country. Responsible amount of each country is calculated Carbon dioxides (responsible amount of Carbon dioxide) can be calculated as Emission amount $\times 142 / 360$ (0.397).

Each country must clear targeted their carbon dioxide res by either decrease of carbon dioxide emission or increase of carbon dioxide fixing.

NOx : Amount of NOx is estimated from the fact that NOx is produced about $1 / 25$ of produced carbon dioxide. When 1 tonne carbon dioxide is produced, $1 / 25$ tonne $\mathrm{NOx}$ is produced in the burning process. The ratio $\mathrm{C} / \mathrm{N}=25 / 1$ is same as plant composition ratio $\mathrm{C} / \mathrm{N}=25 / 1$. Plant eat carbon dioxide and nutrient $\mathrm{N}$ by the ratio $\mathrm{C} /$ $\mathrm{N}=25 / 1$. 14.4 billion tonne NOx is estimated to be produced when 360 billion tonne carbon dioxide is produced.

Many governments such as developed conutries consider NOx as pollution gas and eliminating NOx by the reaction with ammonia. Amount of NOx is so much, carbon dioxide assimilation is retarded very much. Carbon dioxide fixing is retarded very much. And global warming is accelerated very much. For the production of ammonia, much fossil is used and much carbon dioxide is produced and global warming is accelerated so fast.

Fish: Fish eat about 20 times plankton of his weight.

Carbon dioxid $e_{\mathrm{p}}$ : Same weight of carbon dioxide is fixed in the growth of plankton. Therefore 20 times of fish weight carbon dioxide is estimated to be fixed.

Grain: 33 billion tonne grain is produced.

Carbon dioxid $\mathrm{e}_{\mathrm{g}}: 2$ times weight of carbon dioxide is fixed in the production of grain From 66 billion tonne, carbon dioxide 33 billion tonne grain is produced.

Tree grass: From 225 billion tonne carbon dioxide, 225 billion

\begin{tabular}{|c|c|c|c|c|c|c|c|c|}
\hline Country & $\mathrm{Co}_{2}$ emission & $\mathrm{Co}_{2}$ res & $\mathrm{NO}_{\mathrm{x}}$ emission & Fish production & $\mathrm{Co}_{2} \mathrm{f}$ & Grain & $\mathrm{Co}_{2} \mathrm{~g}$ & $\mathrm{Co}_{2} \mathrm{t}$ \\
\hline World & 360 & 142 & 14.4 & 1.0 & 32 & 33 & 66 & 256 \\
\hline China & 106.4 & 41.92 & 4.25 & 0.794 & 15.88 & 5.57 & 11.2 & 100 \\
\hline USA & 51 & 20.2 & 2 & 0.055 & 0.11 & 4.4 & 9 & 51 \\
\hline India & 24.6 & 9.69 & 1 & 0.105 & 2 & 2.95 & 6 & 32 \\
\hline Russia & 19.6 & 7.72 & 0.63 & 0.078 & 0.46 & 0.92 & 0.9 & 1.8 \\
\hline Japan & 12.5 & 4.92 & 0.5 & 0.047 & 0.94 & 0.12 & 0.24 & 0.33 \\
\hline Germany & 7.8 & 2,95 & 0.31 & 0.02 & 0.04 & 0.47 & 0.9 & 0.35 \\
\hline Iran & 6.3 & 2.48 & 0.25 & 0.009 & 0.18 & 0.18 & 0.36 & 0.1 \\
\hline Canada & 5.6 & 2.24 & 0.22 & 0.01 & 0.25 & 0.51 & 1.02 & 4.33 \\
\hline Indonesia & 5 & 1.99 & 1.97 & 0.2 & 0.222 & 0.44 & 0.89 & 1.8 \\
\hline Mexico & 4.7 & 1.85 & 0.2 & 1.9 & - & - & - & - \\
\hline U.K & 4 & 1.58 & 0.16 & 0.05 & 0.1 & 0.2 & 0.4 & 0.24 \\
\hline Turkey & 4 & 1.58 & 0.16 & 0.009 & 0.018 & 0.33 & 0.66 & 0.78 \\
\hline S. Africa & 4 & 1.58 & 0.17 & 0.12 & 0.24 & 1.2 & - & - \\
\hline Italy & 3.5 & 1.38 & 0.14 & 0.035 & 0.7 & 0.16 & 0.3 & 0.3 \\
\hline France & 3.3 & - & 1.37 & 13 & 0.0026 & 0.05 & 0.52 & 1 \\
\hline Poland & 3 & 1.18 & 0.09 & 0.32 & 0.64 & 0.31 & - & - \\
\hline Thailand & 2.8 & 1,10 & 0.11 & 0.026 & 0.52 & 0.38 & 76 & 0.5 \\
\hline Spain & 2.6 & 1.1 & 0.1 & 0.013 & 0.26 & 0.21 & 0.042 & 0.5 \\
\hline Ukraine & 2.3 & 0.9 & 1 & 0.8 & - & - & - & - \\
\hline Egypt & 2.3 & 0.9 & 0.7 & 0.015 & 0.3 & 0.0 .3 & 0.6 & 1 \\
\hline Vietnam & 2.1 & 0.82 & 0.7 & 0.062 & 1.2 & 0.5 & 1 & 0.3 \\
\hline Argentina & 1.9 & 0.74 & 0.01 & 0.18 & 0.51 & 1.02 & 2.8 & - \\
\hline Pakistan & 1.7 & 0.67 & 0.064 & 0.128 & 0.38 & 0.7 & 7.9 & - \\
\hline Australia & 1.35 & 0.53 & 0.0025 & 0.05 & 0.35 & 0.7 & 0.651 & - \\
\hline Philippine & 1.1 & 0.43 & 0.045 & 0.9 & 0.27 & 0.54 & 0.1 & - \\
\hline Nigeria & 0.9 & 0.35 & - & 0.26 & 0.5 & 0.9 & - & - \\
\hline Columbia & 0.8 & 0.31 & 0.003 & 0.06 & 0.08 & 0.04 & 1 & - \\
\hline Venezuela & 0.32 & 0.43 & 0.045 & 0.9 & 0.27 & 0.54 & 0.1 & - \\
\hline Malaysia & 0.28 & 0.43 & 0.045 & 0.9 & 0.27 & 0.54 & 0.1 & - \\
\hline Netherlands & 0.17 & 0.67 & 0.064 & 0.128 & 0.38 & 0.7 & 7.9 & - \\
\hline Belgium & 0.1 & 1.1 & 0.1 & 0.013 & 0.26 & 0.21 & 0.042 & - \\
\hline
\end{tabular}

Note: Carbon dioxide emission, Carbon dioxide res, NOx emission, fish production, Carbon dioxide f (Carbon dioxide fixing by plankton used for fish production), Grain, Carbon dioxide $\mathrm{g}$ (Carbon dioxide fixing used for grain production), Carbon dioxide $\mathrm{t}$ (Carbon dioxide used for Tree Grass production, of many countries in the world Table 1: Carbon dioxide used for tree grass production, of many countries. 
tonne tree and grass are estimate to be produced.

Fish: From 40 billion tonne plankton, 2 billion tonne fish are produced. $1 / 3$ tonne fossil give 1 tonne carbon dioxide.

In the carbon dioxide assimilation process, 1 tonne carbon dioxide react with $18 / 44$ tonne $\mathrm{H}_{2} \mathrm{O}$ using $1 / 25$ tonne $\mathrm{NOx}$.

Carbon dioxide, grain and fish production are obtained from statistic. Plankton weight is estimated from the fact that sardine eat 10 times plankton of his weight. And Tuna (maguro) eat 10 times sardine of his weight. Then we estimated that fish eat 20 times plankton of his weight. In average, Grain: From 66 billion tonne carbon dioxide, 33 billion tonne grain are produced, carbon dioxide fixed in the production of grain is thought to be double of grain. Carbon dioxide (carbon dioxide used for the production of tree, grass) is obtained from carbon dioxide weight minus plankton and grain weight carbon dioxide, grain and fish productions are obtained from statistic.

China emitted 106.4 billion tonne carbon dioxide. Carbon dioxide res is 41.92 billion tonne and emitted 4.26 billion tonne NOx. China produced 0.794 billion tonne fish. China fixed 15.88 billion tonne carbon dioxide by plankton growth. China produced grain 5.57 billion tonne and fixed 11.2 billion tonne carbon dioxide. China has possibility to fix 100 billion tonne carbon dioxide by tree grass carbon dioxide assimilation at $9.98 \mathrm{~m} \mathrm{~km}^{2}$ area.

United States emitted 51.0 billion tonne carbon dioxide. Carbon dioxide res is 20.0 billion tonne and emitted 2 billion tonne NOx and produced 0.055 billion tonne fish and fixed 0.1 billion tonne carbon dioxide by plankton growth. United States produced 4.4 billion tonne grain and fixed 9 billion tonne carbon dioxide. United States can fix 51 billion tonne carbon dioxide by tree grass carbon dioxide assimilation at $5.172 \mathrm{~m} \mathrm{~km}^{2}$ area.

India emitted 24 billion tonne carbon dioxide. India fixed 2 billion tonne carbon dioxide by plankton growth for the production of 0.105 billion tonne fish. India produced grain 2.96 billion tonne and fixed 6 billion tonne carbon dioxide. India can fix 32 billion tonne carbon dioxide by tree grass carbon dioxide assimilation at $3.287 \mathrm{~m} \mathrm{~km}^{2}$ area.

Japan produced 12.5 billion tonne carbon dioxide. Carbon dioxide res is 4.92 tonne and emitted 0.5 billion tonne NOx. Japan produced 0.047 billion tonne fish and fixed 0.94 billion tonne Carbon dioxide by plankton growth. Japan produced 0.1 billion grain and fixed 0.24 billion tonne Carbon dioxide. Japan can fix 3.3 billion tonne Carbon dioxide by tree grass assimilation at $0.378 \mathrm{~m} \mathrm{~km}^{2}$ area.

Total $0.94+0.24+3.3=4.48$ billion tonne carbon dioxide can be fixed. But Japan cannot fix 12.5-4.48=8.02 tonne carbon dioxide at his own land. Because area is narrow Japan increasing 8.02 tonne carbon dioxide. Japan must fix carbon dioxide at surrounding sea by plankton carbon dioxide assimilation.

United Kingdom produced 4 billion carbon dioxide. United Kingdom can fix 0.1 billion tonne carbon dioxide by plankton, 0.4 billion tonne carbon dioxide by grain production, and 2.4 billion tonne carbon dioxide by grass tree production. Total 2.9 billion tonne carbon dioxide can be fixed. United Kingdom increasing 1.1 billion tonne carbon dioxide.

Italy produced 3.5 billion carbon dioxide. Italy can fix 0.7 billion tonne carbon dioxide by plankton, 0.3 billion tonne carbon dioxide by grain production, and 0.3 billion tonne carbon dioxide by tree grass production. Total 1.3 billion tonne carbon dioxide can be fixed. Italy increasing 2.2 billion tonne carbon dioxide. Japan, United Kingdom and Italy cannot fix carbon dioxide at his country because areas are narrow. Japan emitted $1.2 \times 10^{9}$ tonne carbon dioxide in 2015. Japan has area $3.8 \times 10^{5} \mathrm{~km}^{2}$. Fixable carbon dioxide is $3.3 \times 10^{8}$ tonnes. Japan increasing $9 \times 10^{8} \mathrm{k}$ tonne carbon dioxide.

These three counties are increasing carbon dioxide and surrounded by sea. It must decrease carbon dioxide by plankton carbon dioxide assimilation at sea. Total carbon dioxide emission of the world is $3.6 \times$ $10^{10} \mathrm{t}$. We must decrease carbon dioxide emission by the promotion of plankton carbon dioxide assimilation by using NOx given by nature.

\section{Method to Decrease Carbon Dioxide 142 Billion Tonne}

Paris agreement ask us no increase of carbon dioxide. We must fix carbon dioxide same amount carbon dioxide as emission. World is emitting 360 billion tonne carbon dioxide. World is fixing 283 billion tonne carbon dioxide. Therefore 142 billion tonne carbon dioxide is increasing. We must fix 142 billion tonne carbon dioxide.

World is emitting 14.4 billion NOx. About half of emitted NOx is estimated to be eliminated by ammonia. And around half of NOx 7.2 billion tonne NOx is estimated to be released as it is. 1 tonne NOx can fix 25 times of carbon dioxide. Therefore if 7.2 billion tonne NOx is not eliminated, $7.2 \times 25=180$ billion tonne carbon dioxide can be fixed. We must decrease 142 billion ton carbon dioxide. United States: responsible carbon dioxide is 20 billion tonne. USA emitted 51.0 billion carbon dioxide and emitted 2 billion tonne NOx. To eliminate 2 billion tonne NOx 1.13 billion tonne ammonia is necessary. To make 1.13 billion tonne mmonia, 0.2 billion tonne hydrogen gas is required. To make 0.2 billion tonne hydrogen, butane 0.64 billion tonne is required. As the result, 1.76 billion tonne carbon dioxide is released. If NOx elimination is not done, 1.76 billion tonne carbon dioxide can be saved and 50 billion tonne carbon dioxide will be fixed and every plant grow well and produce grain, fish and tree grass well responsible 20 billion tonne COx fix will be done.

NOx concentration limit rule of exhaust gas of car determine the fuel efficiency. By loosening concentration limit, $20 \%$ fuel efficiency will increase and 2 billion tonne carbon dioxide emission will be saved. By effective use of NOx and N, P in the drainage, 5 billion tonne carbon dioxide assimilation is accelerated and grain and fish and meat production will increase.

Japan is emitting 12.5 billion tonne carbon dioxide. Carbon dioxide res is 4.95 billion tonne. 1 billion tonne carbon dioxide is emitting for the elimination of NOx and 1 billion tonne carbon dioxide is emitted for the drainage treatment. If these treatment is stopped, emission of 2 billion ton is saved and concentration of $\mathrm{N}, \mathrm{P}$ increase and carbon dioxide assimilation is accelerated and 5 billion tonne carbon dioxide will be fixed. And $1+1+5=7$ billion ton carbon dioxide is decreased. 7 billion tonne carbon dioxide is 2.05 over the responsible 4.95 billion tonnes to fit Paris accordance.

Japan restricting rice production. Area 11 million hectare (36\% of total rice field) is inhibited to plant. If we cultivate rice at all field, 14 million carbon dioxide can be fixed. If we cultivate two crops rice and wheat at the same field in a year we can fix 30 million tonne carbon dioxide. In Japan very special law about the garbage incinerator was set up in 2002. By the reason much NOx is produced at lower temperature. By this rule, incinerator must be burned at higher temperature than $800^{\circ} \mathrm{C}$ by adding excess fuel to keep higher temperature. Operation of this high temperature incinerator is using much excess fuel releasing much carbon dioxide. Also bonfire was inhibited by the reason bonfire 
produces NOx. By eliminating this law 1 billion tonne carbon dioxide saving will be accomplished [1-5].

\section{Plankton photosynthesis and fish development}

Decrease of half million tonne fish at Setoinland sea (2) means decrease of 10 million tonne carbon dioxide fixing $12.4 \times 10^{8}$ tonne Carbon dioxide $-4.4 \times 10^{5}=8 \times 10^{8}$ tonne Carbon dioxide must be fixed at sea. For the fixing of $8 \times 10^{8}$ tonne Carbon dioxide, Carbon dioxide assimilation must be done at $8 \times 10^{8} / 14.2=5.77 \times 10^{8} \mathrm{~km}^{2}$ sea area, this is 2.3 times wide area of Japan.

Plankton is the foundation of the ocean food chain. Plankton is eaten by many fish and fish is eaten by many fish and animals. I estimated the amount of fixed carbon dioxide by the amount of plankton eaten by caught fish. Two times of caught fish must present 200 million fish were caught. Then 400 million fish must be present. Fish eat ten times plankton. Fish eat 10 times fish. Penguin eat 10 times fish. Birds eat 10 times fish. Whales eat 10 times fish. Seals eat 10 times fish.

If management think carbon dioxide is most important subject, they should eliminate the law about NOx elimination law, and water drainage purification law. Consider sea as firm of fish, firm to fix carbon dioxide. They should eliminate the law to eliminate nutrient N, P and increase $\mathrm{N}, \mathrm{P}$ concentration of sea by releasing NOx and drainage $\mathrm{N}, \mathrm{P}$ as it is.

Japanese are mainly take the fish food as protein source. Because fish contain hyaluronic acid, glucosamine and chondroitin which precursor of anti-aging reagents which co-working with anti-aging gene Klotho(90-96). Japanese may decrease life record. Men 80.50 (third), women 86.63 (top) from the fact that fish production was reduced remarkably by NOx elimination law [6-13].

\section{Carbon Dioxide Assimilation at Sea by Plankton}

The growth of plankton is dependent on light and nutrient availability. Main nutrient is nitrogen $(\mathrm{N})$ and phosphorous (P). Concentration of $\mathrm{N}$ and $\mathrm{P}$ at sea differ greatly by the location. The concentration of surface sea water at $100 \mathrm{~km}$ south of of Muroto (south corner of Shikoku, Japan) is N $1 \mu \mathrm{g} / \mathrm{l}, \mathrm{P} 0.3 \mu \mathrm{g} / \mathrm{l}$.

And concentration at $1000 \mathrm{~m}$ deep sea is water is N $33 \mu \mathrm{g} / \mathrm{l}, \mathrm{P} 2.9$ $\mu \mathrm{l} / \mathrm{l}$. At $1000 \mathrm{~m}$ deep sea water is 30 times rich in nutrition than that of surface sea water. The relation of concentration of $\mathrm{N}$ and $\mathrm{P}$ at different depth is shown below.

Plankton grow at N, P rich sea. Whale shark (Jinbeisame, $10 \mathrm{~m}$ long, weight 20 tonne) is swimming at $50-100 \mathrm{~m}$ deep sea eating plankton. Dr Rei Kawashima, Professor of Nagasaki University took movie by attaching camera at head of whale shark in his Biology gigu project. Whale shark swam 73 times deeper than $50 \mathrm{~m}$ and swam 11 times deeper than $200 \mathrm{~m}$ in 4 days. Whale shark eats plankton mass particle at 300 deep sea. Sun shine is very week at such deep sea. But plankton grow densely, because concentration of $\mathrm{N}$ and $\mathrm{P}$ is higher than shallow sea. This indicate that concentration of $\mathrm{N}$ and $\mathrm{P}$ is more important than sun shine energy. And plankton is growing at very wide range if ocean fixing much carbon dioxide if $\mathrm{N}, \mathrm{P}$ is supplied. If we distribute NOx to air as it is and distribute drainage N, P by ocean dumping, plankton grow very wide range of ocean and we can fix much more carbon dioxide [9-13].

\section{Discussion}

The earth is warmed up by the heart $2.5 \times 10^{15} \mathrm{kcal}$ evolved by the burning of fossil $1.4 \times 10^{10} \mathrm{t}$. The earth is also warmed up by the heart $1 \times 10^{15} \mathrm{kcal}$ evolved by atomic energy. $2.5 \times 10^{15} \mathrm{kcal}$ can be compensated by carbon dioxide assimilation promoted by stopping of NOx elimination, $1 \times 10^{15} \mathrm{kcal}$ must be absorbed by extra carbon dioxide assimilation by extra-increase of nutrient $\mathrm{N}, \mathrm{P}$ obtained by extra agitation of sea water. Plankton grow infinitively if enough nutrient $\mathrm{N}$, $\mathrm{P}$ are supplied by agitation of sea water. We must study how to agitate sea water effectively.

\section{Conclusion}

Promotion of Carbon dioxide is most important act for protection of global warming. Elimination of law which forced to eliminate nutrient $\mathrm{N}, \mathrm{P}$ and studies on agitation of sea water are important subject for the protection of global warming.

\section{References}

1. Ozaki S (1993) Recycle of nitrogen and phosphorous for the increase of food production. New Food Industry 10: 33-39.

2. Ozaki S (2016) Methods to protect global warming. Adv Tech Biol Med 4: 181

3. Ozaki S (2016) Methods to protect global warming, Food production increase way. New Food Industry 8: 47-52.

4. Ozaki S (2016) Global warming can be protected by promotion of $\mathrm{CO}_{2}$ assimilation using NOx. J Climatol Weather Forecasting 4: 171.

5. Ozaki S (2016) Global warming can be protected by promotion of plankton $\mathrm{CO}_{2}$ assimilation. J Marine Sci Res Dev 6: 213

6. Henson SA, Sarmiento JL, Dunne JP, Bopp L, Lima I, et al. (2010) Detection of anthropogenic climate change in satellite records of ocean chlorophyll and productivity. Biogeosciences 7: 621-640.

7. Steinacher M, Joos F, Frölicher TL, Bopp L, Cadule P, et al. (2010) Projected 21st century decrease in marine productivity: a multi-model analysis. Biogeosciences 7: 979-1005.

8. Richtel M (2007) Recruiting plankton to fight global warming. New York Times.

9. Charlson RJ, Lovelock JE, Andreae MO, Warren SG (1987) Oceanic phytoplankton, atmospheric sulphur, cloud albedo and climate. Nature 326 655-661.

10. Quinn PK, Bates TS (2011) The case against climate regulation via oceanic phytoplankton sulphur emissions. Nature 480: 51-56.

11. Calbet $A$ (2008) The trophic roles of microzooplankton in marine systems. ICES Journal of Marine Science 65: 325-331.

12. Arrigo Kevin R (2005) Marine microorganisms and global nutrient cycles". Nature 437: 349-355.

13. Fanning Kent $A$ (1989) Influence of atmospheric pollution on nutrient limitation in the ocean. Nature 339: 460-463. 